\title{
Record of a bypass on the oral siphon of Ascidia sydneiensis (Tunicata: Ascidiacea) in a tropical bay from south-eastern Brazil
}

\author{
Paulo Cezar Azevedo Silva1 ${ }^{1}$, Géssica Cristine Maia Oliveira ${ }^{1,2}{ }^{\oplus}$, Danielle \\ Fernandes Barboza ${ }^{1,2}$, Luís Felipe Skinner ${ }^{1,2 *}$ (1)
}

\begin{abstract}
1 Universidade do Estado do Rio de Janeiro (UERJ/FFP) Departamento de Ciências, Rio de Janeiro, Brasil (Rua Dr. Francisco Portela, 1470 - Patronato - São Gonçalo - 24435-005 - RJ - Brazil)

2 Programa de Pós-Graduação em Oceanografia (PPG-OCN/UERJ), Rio de Janeiro, Brasil (Rua São Francisco Xavier, 524 - sala $4018 /$ bloco E - Maracanã, 20550-013 - RJ - Brazil)
\end{abstract}

*Corresponding author: Iskinner@uerj.br

Ascidia sydneiensis Stimpson, 1855 is a solitary ascidian (Order Phlebobranchia) first described in the China Sea and Japan. Recently, it has been recorded in subtropical and tropical regions and is abundant in the Caribbean (Rocha et al., 2005; Worms, 2020). In Brazil, it was first recorded in the São Paulo State (Bjornberg, 1956) and ranges from Ceará to Santa Catarina (Rodrigues, 1962; Rocha and Nasser, 1998; Rocha and Costa, 2005; Rocha and Kremmer, 2005; Rocha et al., 2012). On the coast of Rio de Janeiro State, it was recorded at Ilha Grande Bay, Sepetiba Bay, Arraial do Cabo, and Búzios (Marins et al., 2010; Granthon-Costa et al., 2016).

Ascidia sydneiensis occurs on both natural and artificial hard substrates (Rodrigues, 1962; Rocha and Kremmer, 2005). Ascidia sydneiensis has a cartilaginous and soft tunic and, in vivo, is colourless or grayish and usually covered by epibionts. The atrial siphon, which is lobed and has strong circular muscles, is distant from one to two-thirds of its body length from the terminal oral siphon (Kott, 1985). This note reports the occurrence of an individual of $A$. sydneiensis with a filtering anatomical anomaly.

An individual with an additional siphon opening (Figure 1) was collected in January/2018 from a

Submitted on: 2/June/ 2020

Approved on: 19/September/2020

Editor: Rubens M. Lopes

2020 The authors. This is an open access article distributed under the terms of the Creative Commons license. natural substrate at Ilha da Amarração, next to llha Grande, Rio de Janeiro state, Brazil (2310'58.0"S, $\left.44^{\circ} 10^{\prime} 47.7^{\prime \prime} \mathrm{W}\right)$. This atypical individual had a small projection with rims and other morphological features, on the tunic next to a larger oral siphon. After collection, the animal was anesthetized with menthol and fixed in 10\% formaldehyde. The presence of the third opening was not noticed during the removal of the animal from the substrate but was noted in the laboratory during dissection. Part of the larger oral siphon on the mantle projects into a secondary siphon (bypass) that connects to the tunic and then to the exterior. Both siphons show evident lobes, seven on the larger and five on smaller. The latter also shows projections on its margins, similar to those reported by Kott (1985) and Bonnet and Rocha (2011). Siphon musculature has longitudinal and circular muscle bundles, with the former being more developed. Our specimen showed marked longitudinal muscles along the siphon lobes. Seven bands were observed on the larger siphon, and four on the smaller. There was a gap between the two oral siphons, with an almost absence of muscular fibers and some of the muscle bundles showing changes in direction (Fig. 2).

Both siphons lead to a shared channel with a single tentacular region that projects into the branchial sac. No other structural modifications were observed as compared to the normal anatomy of $A$. sydneiensis. Although filtration activity through the additional siphon was not observed, we assume that 

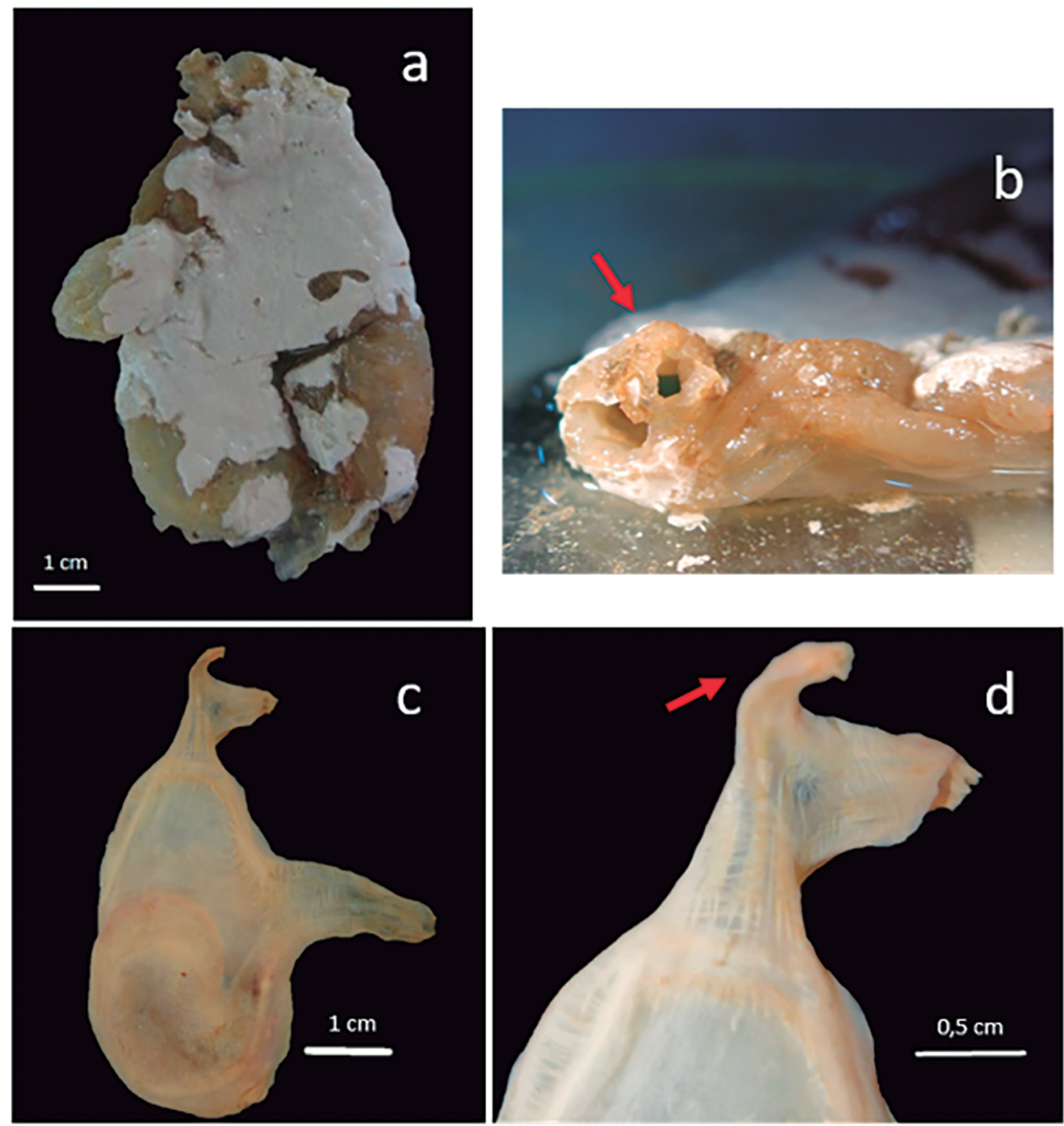

Figure 1. Ascidia sydneiensis with anomaly in the filtering system, with two oral and one atrial siphons: a) external appearance of the specimen inside the tunic; b) detail of the oral siphon with the tunic, the red arrow indicates the second siphon; c) appearance of the specimen outside the tunic; and d) detail of the anomaly in the oral siphon with the red arrow indicating the second oral siphon.
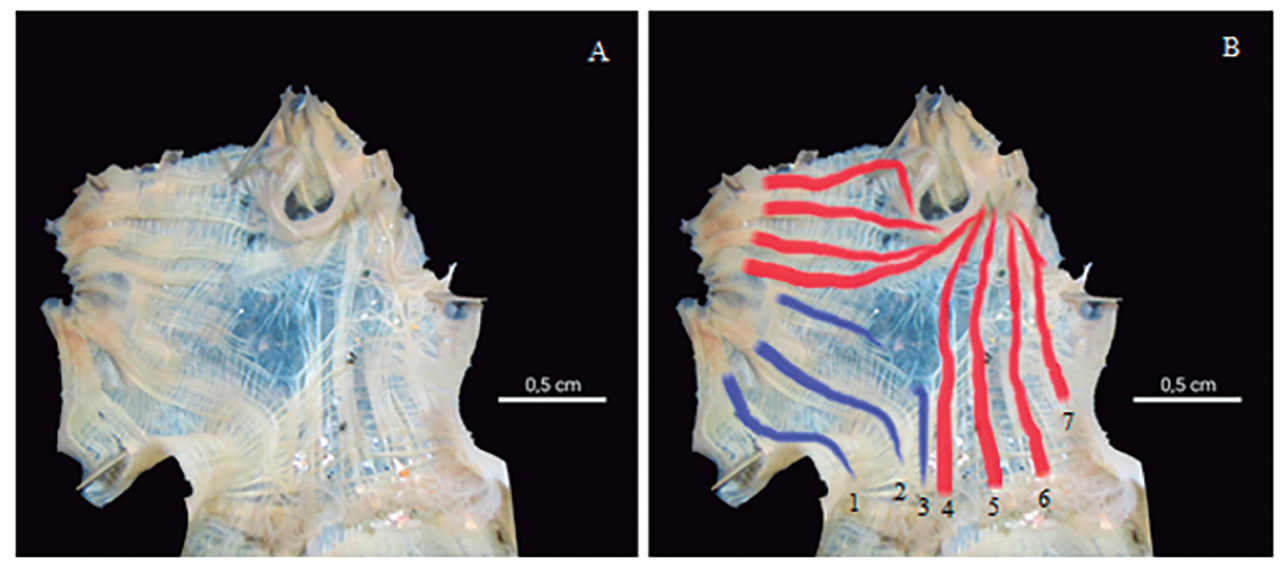

Figure 2. Ascidia sydneiensis individual modification in the filtering structure: A) distribution of the muscle bundles present in the siphons; and B) Siphon muscle bundles shown indicating their distribution between the siphons. Muscles bundles colored red are shared by both siphons, while those colored blue are exclusive to the major siphon. 
it was functional as the syphon opened when relaxed with menthol and because of the presence of shared muscle bundles on both siphons.

In contrast to the bypass recorded here, the presence of additional siphonal openings in ascidians in the wild has only been reported for atrial siphons, never on oral siphon. Such duplications and bypasses can occur naturally or be experimentally induced (Geoge, 1937; Berril, 1951). Styela clava and Polycarpa mytiligera (Order Stolidobranchia) have been reported with an additional atrial siphon resulting from predation (Epelbaum et al., 2007; Gordon \& Shenkar, 2018). The experimental obstruction of the atrial siphon of Styela plicata resulted in a bypass on that organ, highlighting the plasticity of the ascidian body growth (George, 1937). Some species, such as Ascidiella aspersa and Ciona intestinalis (Order Phlebobranchia), have shown true duplication of their atrial siphons including internal structures (Kerkenberg and Hofmann, 1989; Hamanda, 2015). Individuals of the genera Phallusia, Ascidia, Ciona, and Ascidiella had two atrial siphons on the third day after settlement, although those doubled siphons merged at the end of metamorphosis, resulting in a single structure (Kerkenberg and Hormann, 1989). Thus, if any abnormality occurs during this developmental stage, an anomalous adult could result, such as one with a duplication of the atrial siphon (Epelbaum et al., 2007).

The dual opening of the oral siphon observed in A. sydineiensis is suggested to be either regeneration after predator damage to the siphon or obstruction. A new siphon, or new opening, can develop in just a few hours (George, 1937), originated from epidermal or atrial epithelial tissues (Berril, 1951). As both siphonal openings share several structures, such as a ciliated groove and tentacles, it can be considered a bypass. However, even that possibility raises questions about regeneration, as the "regenerated" siphon has a similar rim structure and reflects the plasticity of the individual in adapting to water and food intakes. The evolutionary meaning of regeneration or the reorientation of body structures such as the neural complex, internal organs, the digestive system, and even peripheral structures such as siphons in ascidians, can reflect a recovery from predation or competitive pressure from overgrowth (Brow et al., 2009; Dahlberg et al., 2009; Gordon \& Shenkar, 2015). Sublethal predation may be responsible for maintaining evolutionary regenerative capacity of ascidians (Lindsay, 2010; Gordon and Shenkar, 2018).

Between 2009 and 2020, 245 individuals of the genus Ascidia were collected during predator exclusion experiments in Rio de Janeiro State and just a single case of a siphonal bypass was recorded among 126 individuals of $A$. sydneiensis. Although ascidians with some degree of duplication of the atrial siphon and associated structures are rare in nature (Epelbaum, 2007), this phenomenon could be quite significant for future studies in areas such as adaptative ecology, evolutionary biology, embryology, and morphology that use ascidians as a model.

\section{ACKNOWLEDGEMENTS}

We thank to both referees for their criticism, suggestions, and theoretical discussion that improved this note. This work was funded by Fundação de Amparo à Pesquisa do Estado do Rio de Janeiro - FAPERJ (Proc. \# E-26 / 11.454 / 2011). The authors would like to thank FAPERJ by the TCT research grant to PCAF, and PROATEC to GCMO, and a scholarship awarded to DFB through the Coordenação de Aperfeiçoamento de Pessoal de Nível Superior - Brasil (CAPES) - Financial Code 001, the logistical support provided by CEADS-UERJ and the research authorization of the Parque Estadual da Ilha Grande (INEA - Aut. № 025/2017).

\section{AUTHOR CONTRIBUTIONS}

P.C.A.S: Original draft, Conceptualization, Methodology, Validation, Formal Analysis, Visualization, Writing-Reviewing and Editing.

G.C.M.O: Original draft, Conceptualization, Methodology, Validation, Formal Analysis, Visualization, Writing-Reviewing and Editing.

D.F.B.:Original draft, Conceptualization, Methodology, Validation, Formal Analysis, Visualization, WritingReviewing and Editing.

L.F.S.: Original draft, Conceptualization, Methodology, Project administration, Validation, Formal Analysis, Funding acquisition, Visualization, Writing-Reviewing and Editing. 


\section{REFERENCES}

BERRILL, N. J. 1951. Regeneration and budding in tunicates. Biological Reviews, 26(4), 456-475, DOI: https://doi. org/10.1111/j.1469-185X.1951.tb01207.x

BROWN, F. D., KEELING, E. L., LE, A. D. \& SWALLA, B. J. 2009. Whole body regeneration in a colonial ascidian, Botrylloides violaceus. Journal of Experimental Zoology. Part B, Molecular and Developmental Evolution, 312(8), 885-900, DOI: https:// doi.org/10.1002/jez.b.21303

DAHLBERG, C., AUGER, H., DUPONT, S., SASAKURA, Y., THORNDYKE, M. \& JOLY, J. S. 2009. Refining the Ciona intestinalis model of central nervous system regeneration. PLoS One, 4(2), e4458, DOI: https://doi.org/10.1371/journal.pone.0004458

EMPELBAUM, A., PEARCE, C. M. \& THERRIAULT, T. W. 2007. A case of atrial siphon duplication in Styela clava (Tunicata: Ascidiacea). Marine Biodiversity Records, 2, e32, DOI: https://doi. org/10.1017/S1755267208000365

GEORGE, W. C. 1937. The formation of new siphon openings in the tunicate, Styela plicata. Journal of the Elisha Mitchell Scientific Society, 53(1), 87-92. Available at: http://www.jstor. org/stable/24332081 [Accessed: 29 June. 2020]

GRANTHOM-COSTA, L. V., FERREIRA, C. G. W. \& DIAS, G. M. 2016. Biodiversity of ascidians in a heterogeneous bay from southeastern Brazil. Management of Biological Invasions, 7(1), 5-12, DOI: http://dx.doi.org/10.3391/mbi.2016.7.1.02

GORDON, T. \& SHENKAR, N. 2018. Solitary ascidians as model organisms in regenerative biology studies. In: KLOC, M. \& KUBIAK, J. (eds.). Marine organisms as model systems in biology and medicine. Results and problems in cell differentiation. vol. 65. Cham: Springer, DOI: https://doi.org/10.1007/978-3-319-92486-1_15

HAMADA, M., GORICKI, S., BYERLY, M. S., SATOH, N. \& JEFFERY, W. R. 2015. Evolution of the chordate regeneration blastema: differential gene expression and conserved role of notch signaling during siphon regeneration in the ascidian Ciona. Developmental Biology, 405(2), 304-315, DOl: https://doi.org/10.1016/j.ydbio.2015.07.017

ISHII, T., TANEDA, Y. \& SAITO, Y. 1993. Polarity and body pattern in ascidian chimeras formed between normal (situs normale viscerum) and reversed (situs inversus viscerum) bodies. Journal of Experimental Zoology, 269(4), 336-348, DOI: https://doi.org/10.1002/jez.1402690407
KOTT, P. 1985. The Australian Ascidiacea Part 1, Phlebobranchia and Stolidobranchia. Memoirs of the Queensland Museum, 23, 1-440.

LINDSAY, S. M. 2010. Frequency of injury and the ecology of regeneration in marine benthic invertebrates. Integrative and Comparative Biology, 50(4), 479-493, DOI: https://doi. org/10.1093/icb/icq099

MARINS, F. O., NOVAES, R. L. M., ROCHA, R. M. \& JUNQUEIRA, A. O. R. 2010. Non indigenous ascidians in port and natural environments in a tropical Brazilian bay. Zoologia (Curitiba), 27(2), 213-221, DOI: https://doi.org/10.1590/s198446702010000200009 MONNIOT, C. 1983. Ascidies littorales de Guadeloupe. IV - Styelidae. Bulletin du Muséum National d'Histoire Naturelle, 5(2), 423-456.

NIERMANN-KERKENBERG, E. \& HOFMANN, D. K. 1989. Fertilization and normal development in Ascidiella aspersa (Tunicata) studied with Nomarski-optics. Helgoländer Meeresuntersuchungen, 43(2), 245-258, DOI: https://doi.org/10.1007/ bf02367902

ROCHA, R. M. \& COSTA, L. V. G. 2005. Ascidians (Urochordata: Ascidiacea) from Arraial do Cabo, Rio de Janeiro, Brazil. Iheringia. Série Zoologia, 95(1), 57-64, DOI: https://doi. org/10.1590/S0073-47212005000100009

ROCHA, R. M., KREMER, L. P., BAPTISTA, M. S. \& METRI, R. 2009. Bivalve cultures provide habitat for exotic tunicates in southern Brazil. Aquatic Invasions, 4(1), 195-205, DOI: https:// doi.org/10.3391/ai.2009.4.1.20

ROCHA, R. M. \& NASSER, C. M. 1998. Some Ascidians (Tunicata, Ascidiacea) from Paraná State, Southern Brazil. Revista Brasileira de Zoologia, 15(3), 633-642, DOI: https://doi. org/10.1590/S0101-81751998000300009

ROCHA, R. M., FARIA, S. B. \& MORENO, T. R. 2005. Ascidians from Bocas del Toro, Panamá. I. Biodiversity. Caribbean Journal of Science, 41, 600-612.

ROCHA, R. M., ZANATA, T. B. \& MORENO, T. R. 2012. Keys for the identification of families and genera of Atlantic shallow water ascidians. Biota Neotropica, 12(1), 269-303.

RODRIGUES, S. A. 1966. Notes on Brazilian ascidians. I. Papéis Avulsos do Departamento de Zoologia da Universidade de São Paulo, 19(8), 95-115. 